\title{
Assessment of Women's Practices Toward Cervical Cancer Screening at Outpatient Clinics in Baghdad Maternity Hospitals
}

\author{
Fatima Fadel Benyian, MSc ${ }^{1}$, Dr. Rabea Mohsen Ali, PhD. ${ }^{2}$ \\ ${ }^{1}$ Maternal and Neonatal Nursing Department, College of Nursing, University of Baghdad, Baghdad, Iraq \\ ${ }^{2}$ Professor, Maternal and Neonatal Nursing Department, College of Nursing, University of Baghdad, Baghdad, Iraq
}

\begin{abstract}
Background: Cervical cancer is one of the main reasons for gynaecological cancer death that occurs worldwide. Papanicolaou (Pap) smear is an effective and affordable test for early detection of cellular changes in the cervix. Pap smear plays an important role in reducing cervical cancer morbidity and mortality rate Developed countries succeeded in controlling the incidence of cervical cancer, while developing countries have failed miserably in this regard. Developed countries succeeded and it is largely attributable to the systematic and common use of Pap smear screening. Objective: To assess women's practices toward cervical cancer screening and find out the association between women's practices and their demographic variables. Methods: A cross sectional study was conducted between October 2016 and February 2017 at Baghdad maternity hospitals. A questionnaire was constructed to gather information from (400) married women, the data were collected through interview and self administered questionnaire which used. Data are analyzed through the use of SPSS version 20. Results: This study shows that the women's practices concerning cervical cancer is poor. There are statistical significant differences between women's practices and duration of marriage,while there are no statistical significant differences between women's practices and the left over demographic variables. Conclusion: This study shows that the women's practices toward cervical cancer screening is poor. Recommendation: There is a need to provide knowledge about cervical cancer screening, and encourage women to take pap smear test to prevent cervical cancer.
\end{abstract}

Keywords: Practices, Cervical Cancer, Screening , Pap smear

\section{Introduction}

Cancer of the cervix is rated as the fourth most common cancer and cancer deaths among the female population in (2012), an estimation was $(528,000)$ new patients of cervical cancer with $(266,000)$ deaths. The majority of burden accounting for about (85\%) has occurred in the less developed countries of the total cases of cervical cancer [1].

Since the prescence and common use of the Pap test, which helps in the early detection of precancerous cervical lesions at an early stage, and the incidence of cancer of the cervix was dramatically decreased from $(32 / 100.000)$ female in the $(1940$ s) to $(8.3 / 100.000)$ female in the $(1980 \mathrm{~s})$. Yet, in many parts of developing countries, there is still risk of cervical cancer, which cause significant morbidity and mortality [2].

Cervical cancer starts with abnormal changes in the cervical cellular lining or surface. Typically, these changes usually occur in the cervical squamous-columnar junction. Here, cylindrical secretory epithelial cells (columnar) meet the protective flat epithelial cells (squamous) from the outer cervix and vagina in what is termed the transformation zone. The continuous replacement of columnar epithelial cells by squamous epithelial cells in this area makes these cells vulnerable to take up foreign or abnormal genetic material [3].

Cervical cancer screening is very effective because of the presence of a precursor lesion, cervical intraepithelial neoplasia (CIN), helps determine whether there is a need for further tests. Over a long period lesions start as dysplasia and progress in a predictable process, allowing a great opportunity for intervention at a precancerous stage [4].

Cervical cancer screening must beginning at (25) years of age every three years. The interval is extended to every five years for women's age more than (50) years. The women aged (65) years or more, they should screen only when they haven't screened since their age was (50) years, or when they have an abnormality of a recent result of the test [5].

The screenings of cervical cancer in many developing countries are not available or are poorly accessible. Cervical cancer knowledge among female population is still limited and thus women are less willing to receive cervical cancer screening. Educational levels and misconceptions may also contribute to the poor uptake of cervical cancer screening [6].

The disease diagnosis based not only on a Pap test. Cervical cancer can be diagnosed with a biopsy from tissue. When found an abnormality result of a Pap test should perform a colposcopy and cervical biopsy. When found a visible lesions should also perform a biopsy. When found an abnormality result from the physical examination may perform an ultrasound or computed tomography (CT) to confirm the results and determine the disease extend of invasion [7].

The American College of Obstetricians and Gynecologists (ACOG,2003), the American Academy of Family Physicians and the US Preventive Services Task Force (USPSTF) recommend that all women must be screen with a Pap test by nearly three years after onset of vaginal intercourse, but

Volume 6 Issue 12, December 2017 


\section{International Journal of Science and Research (IJSR) \\ ISSN (Online): 2319-7064}

Index Copernicus Value (2016): 79.57 | Impact Factor (2015): 6.391

not latter of (21) years old. It should be done at least once every ( 2 or 3 years) starting within three years after a women to have sexual intercourse. Once three normal yearly Pap test has documented, the period of interval for continual monitoring of Pap test may be increased at the decision of the physician and women. Cervical cancer screening may be stopped in the women's age (65-70) years who had at least three Pap test with normal results and there has been no abnormal Pap test in the last ten years. The decision to stop the screening is taken in consultation with the health care provider. For the total hysterectomy cases do not need to receive cervical screening, except if the hysterectomy was conducted as a management for pre-invasive or invasive stage of cervical cancer. In all women with abnormal Pap tests have shown mild dysplasias, it is important to treat any accompanying inflammatory pathology and repeat the Pap test [8].

\section{Methods}

Cross-sectional (descriptive analytic) study was done among married women. The study was performed between October 2016 and February 2017 in Baghdad maternity hospitals. Non probability (purposive sample) used to collect the data from (400) married women who attained outpatient clinics in maternity hospitals. A questionnaire constructed by the researchers to identify women's practices about cervical cancer and screening. A pilot study conducted in order to determine the reliability of the questionnaire in a sample of (20) women who excluded from the study sample $(\mathrm{r} 1=0.96)$. Content validity was determined through a panel of (17) experts their experience mean and SD was $28.82 \mp 7.5$. The data were collected after obtaining the agreement from women to participate in this study. The study instrument was consisted of two parts which include: Socio demographic characteristics, women's practices toward cervical cancer and screening. Data are analyzed through the use of SPSS (Statistical Process for Social Sciences) version 20 and excel.

\section{Results}

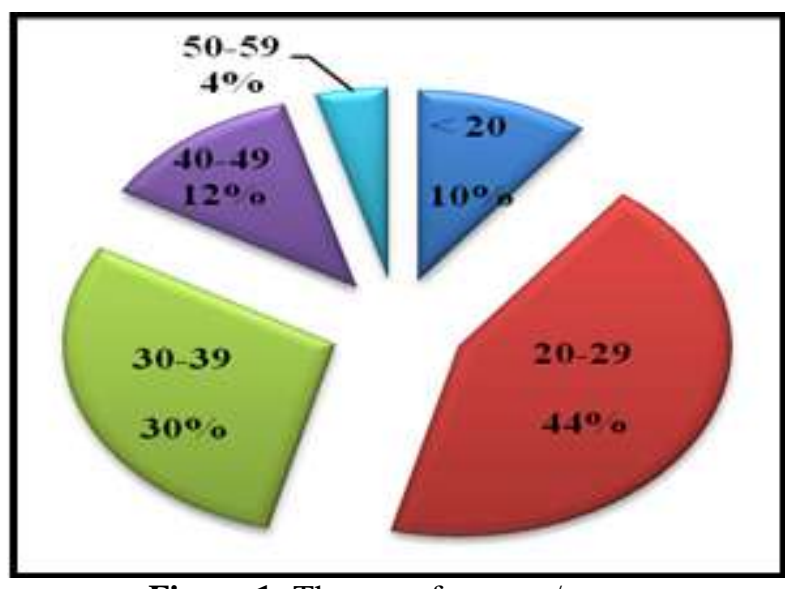

Figure 1: The age of women/ years

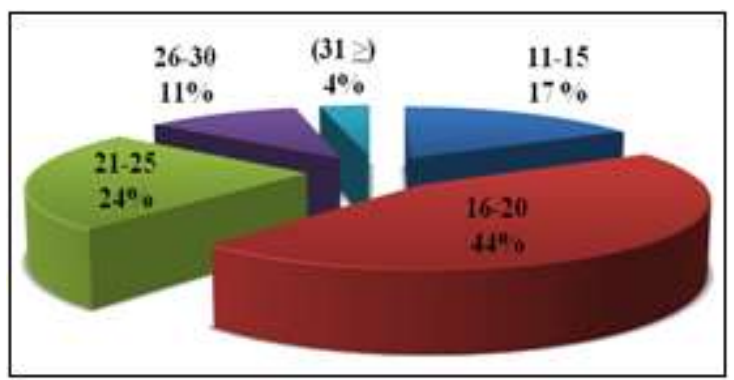

Figure 2: The age at marriage / years

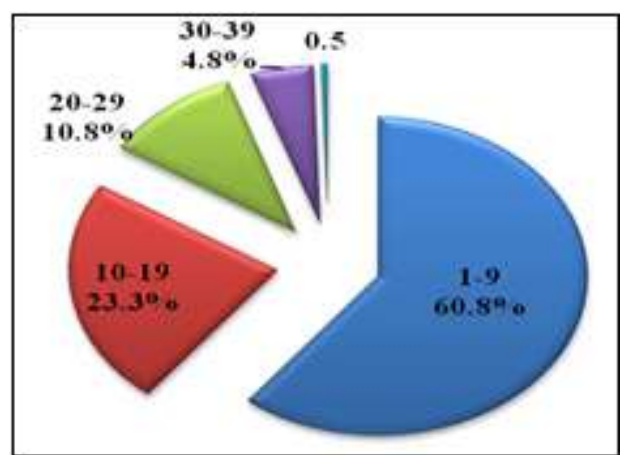

Figure 3: The duration of marriage/ years

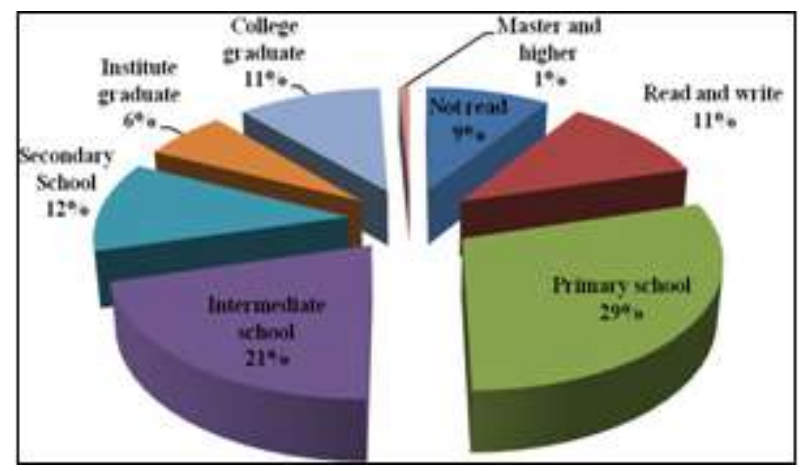

Figure 4: The educational level of study sample

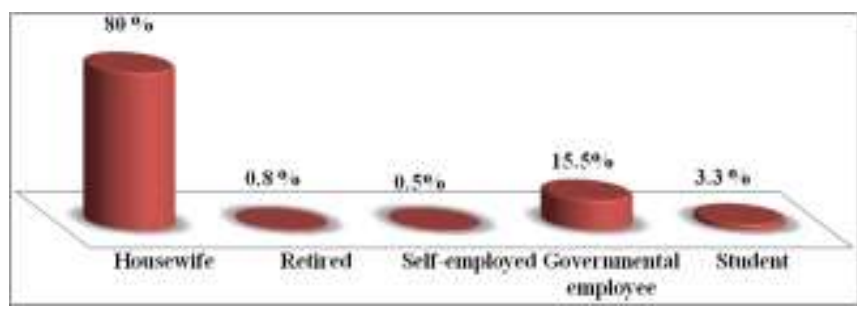

Figure 5: women's occupation

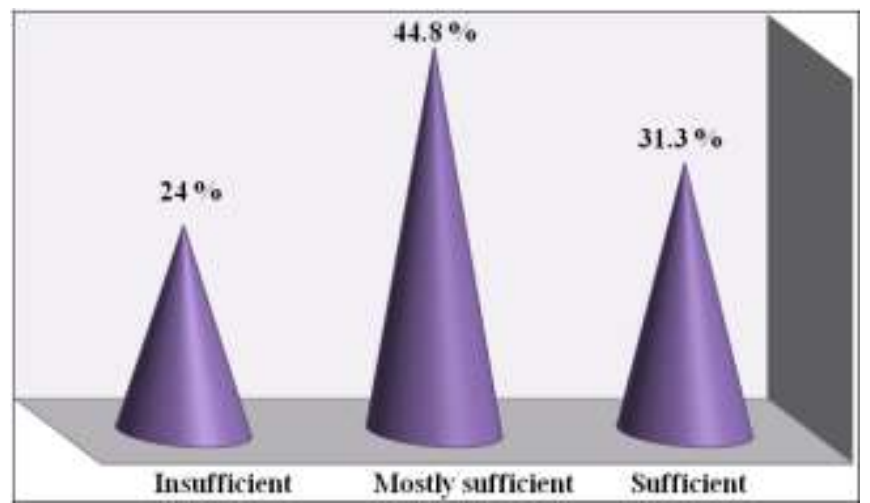

Figure 6: The monthly income of study sample

Volume 6 Issue 12, December 2017 www.ijsr.net 
International Journal of Science and Research (IJSR)

ISSN (Online): 2319-7064

Index Copernicus Value (2016): 79.57 | Impact Factor (2015): 6.391

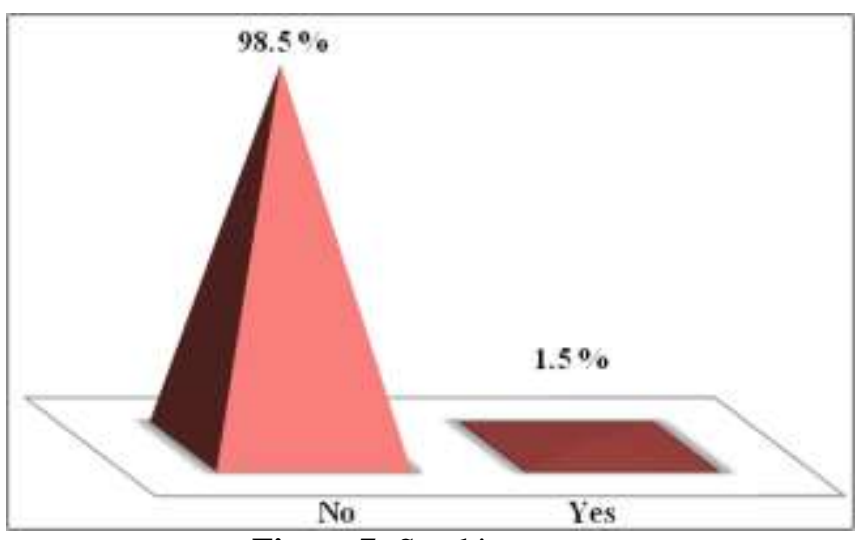

Figure 7: Smoking status

Table 1: Practices of Women Concerning Cervical Cancer Screening $(n=400)$

\begin{tabular}{|l|c|c|}
\hline Practices variables & F & \% \\
\hline Have a Pap smear & $\mathbf{3 7 1}$ & $\mathbf{9 2 . 8}$ \\
\hline No & 29 & 7.2 \\
\hline Yes & 371 & 92.8 \\
\hline Age of first Pap smear test / years \\
\hline None & 5 & 1.3 \\
\hline$<20$ & $\mathbf{1 1}$ & $\mathbf{2 . 8}$ \\
\hline $\mathbf{2 0 - 2 9}$ & 9 & 2.1 \\
\hline $30-39$ & &
\end{tabular}

\begin{tabular}{|c|c|c|}
\hline $40-49$ & 4 & 1.0 \\
\hline \multicolumn{3}{|c|}{ Frequency of Pap smear } \\
\hline None & 371 & 92.8 \\
\hline 1 & 26 & 6.5 \\
\hline 2 & 2 & .4 \\
\hline$(3 \geq)$ & 1 & .3 \\
\hline \multicolumn{3}{|c|}{ Period of last Pap smear test /years } \\
\hline None & 371 & 92.8 \\
\hline $1-3$ & 11 & 2.8 \\
\hline $4-6$ & 7 & 1.7 \\
\hline $7-9$ & 3 & .8 \\
\hline$(10 \geq)$ & 8 & 1.9 \\
\hline \multicolumn{3}{|c|}{ Reasons for don't have a Pap smear } \\
\hline Don't know the test & 263 & 65.8 \\
\hline Fear & 1 & .2 \\
\hline Embarrassment & 2 & .5 \\
\hline Not necessary & 103 & 25.8 \\
\hline Expensive & 2 & .5 \\
\hline Have a Pap smear & 29 & 7.2 \\
\hline
\end{tabular}

Table (1) results show that the most $(92.8 \%)$ of the study sample don't have a Pap smear, while only (7.2\%) have a Pap smear. Regarding Reasons for don't have a Pap smear more than two third (65.8\%) of participants because don't know the test and approximately a quarter of them (25.8\%) because "not necessary", while the lowest percentage $(0.2 \%)$ of them because "fear".

Table 3: Association between women's Practices and Socio Demographic variables $(n=400)$

\begin{tabular}{|c|c|c|c|c|c|c|c|c|c|}
\hline \multirow{2}{*}{\multicolumn{2}{|c|}{ Socio Demographic variables }} & \multirow{2}{*}{\multicolumn{4}{|c|}{ Practices }} & \multirow{2}{*}{\multicolumn{3}{|c|}{ Chi square statistics }} & \multirow{3}{*}{ Sig. } \\
\hline & & & & & & & & & \\
\hline & & $\mathrm{F}$ & $\%$ & $\mathrm{~F}$ & $\%$ & Value & $\mathrm{df}$ & P-value & \\
\hline \multirow{5}{*}{ Age / years } & $<20$ & 0 & 0.0 & 41 & 100 & \multirow{5}{*}{9.236} & \multirow{5}{*}{4} & \multirow{5}{*}{.055} & \multirow{5}{*}{ NS. } \\
\hline & $20-29$ & 9 & 5.1 & 166 & 94.9 & & & & \\
\hline & $30-39$ & 11 & 9.3 & 107 & 90.7 & & & & \\
\hline & $40-49$ & 7 & 14.3 & 42 & 85.7 & & & & \\
\hline & $50-59$ & 2 & 11.8 & 15 & 88.2 & & & & \\
\hline \multirow{5}{*}{$\begin{array}{c}\text { Duration of } \\
\text { marriage / years }\end{array}$} & $1-9$ & 10 & 4.1 & 233 & 95.9 & \multirow{5}{*}{12.258} & \multirow{5}{*}{4} & \multirow{5}{*}{.016} & \multirow{5}{*}{ S. } \\
\hline & $10-19$ & 11 & 11.8 & 82 & 88.2 & & & & \\
\hline & $20-29$ & 4 & 9.3 & 39 & 90.7 & & & & \\
\hline & $30-39$ & 4 & 21.1 & 15 & 78.9 & & & & \\
\hline & $40-49$ & 0 & 0.0 & 2 & 100 & & & & \\
\hline \multirow{8}{*}{ Educational level } & Not read & 3 & 8.1 & 34 & 91.9 & \multirow{8}{*}{4.285} & \multirow{8}{*}{7} & \multirow{8}{*}{.746} & \multirow{8}{*}{ NS. } \\
\hline & Read and write & 1 & 2.2 & 44 & 97.8 & & & & \\
\hline & Primary school & 11 & 9.3 & 107 & 90.7 & & & & \\
\hline & Intermediate school & 8 & 9.6 & 75 & 90.4 & & & & \\
\hline & Secondary School & 3 & 6.5 & 43 & 93.5 & & & & \\
\hline & Institute graduate & 1 & 4.0 & 24 & 96 & & & & \\
\hline & College graduate & 2 & 4.7 & 41 & 95.3 & & & & \\
\hline & Master and higher & 0 & 0.0 & 3 & 100 & & & & \\
\hline \multirow{5}{*}{$\begin{array}{l}\text { Occupational } \\
\text { Status }\end{array}$} & Student & 0 & 0.0 & 13 & 100 & \multirow{5}{*}{1.498} & \multirow{5}{*}{4} & \multirow{5}{*}{.827} & \multirow{5}{*}{ NS. } \\
\hline & Governmental employee & 5 & 8.1 & 57 & 91.9 & & & & \\
\hline & Self-employed & 0 & 0.0 & 2 & 100 & & & & \\
\hline & Retired & 0 & 0.0 & 3 & 100 & & & & \\
\hline & Housewife & 24 & 7.5 & 296 & 92.5 & & & & \\
\hline & Sufficient & 10 & 8.0 & 115 & 92 & & & & \\
\hline (womens point of & Mostly sufficient & 11 & 6.1 & 168 & $93.9 \%$ & .597 & 2 & .742 & NS. \\
\hline & Insufficient & 8 & 8.3 & 88 & $91.7 \%$ & & & & \\
\hline
\end{tabular}

(df) degree of freedom, (Sig) significant Probability value (P < 0.05), (NS) Non Significant, (s) significant.

Table (2) results show that there are statistical significant differences between Pap smear test and duration of marriage, while there are no statistical significant differences between women's practices and (age, educational level, occupation status, monthly income).

\section{Discussion}

The screenings of cervical cancer in many developing countries are not available or are poorly accessible. Cervical cancer knowledge among female population is still limited

\title{
Volume 6 Issue 12, December 2017
}

\author{
www.ijsr.net
}

Licensed Under Creative Commons Attribution CC BY 


\section{International Journal of Science and Research (IJSR) \\ ISSN (Online): 2319-7064}

Index Copernicus Value (2016): 79.57 | Impact Factor (2015): 6.391

and thus women are less willing to receive cervical cancer screening. Educational levels and misconceptions may also contribute to the poor uptake of cervical cancer screening [6].

This study shows that the study population practices was poor and that could be due to the deficit of cervical cancer knowledge. In developed countries the level of knowledge was found to be high. Knowing cervical cancer risk factors is very important that can make women to avoid them, which leads to the prevention of cervical cancer. These results are consistent and supported by Bansal who found that the majority of respondents $(90.5 \%)$ had never screened with the Pap smear test [9]. Shrestha who stated that the uptake of Pap smear test was only $(10.5 \%)$ in their respondents [10]. Amarin who mentioned that the most of the study population $(85.7 \%)$ hadn't uptake Pap smear and $(14.3 \%)$ had received the Pap smear test [11]. Sait who found that only $(16.8 \%)$ had undergone the test in their study population [12]. John who showed that only (14.2\%) had ever been screened with a Pap smear test [13]. Al Sairafi \& Mohamed who reported that the Pap smear test among studied women only (35.2\%) [14].

These results are inconsistent with the studies done by Cerigo who found that the majority of the study population (96\%) had received a Pap smear [15]. Uysal \& Birsel who reported that more than two thirds of their respondents (68.5\%) screened with Pap smear test, about one third (31.5 $\%)$ of them hadn't screen [16].

Regarding the reasons of didn't have Pap smear test the higher percentage of participants $(65.8 \%)$ were "don't know", also approximately quarter of study sample (25.8\%) were answered with "not necessary" while the lowest percentage $(0.2 \%)$ of them were "fear".

These results are consistent and supported with the studies conducted by Bansal who demonstrated that more than two thirds of women $(65 \%)$ were unaware of the cervical screening test [9]. John who showed that one third of the study population $(30.7 \%)$ the barrier was lack of knowledge [13]. Amarin who reported that inadequate knowledge toward the screening was the major barriers to Pap smear screening [11]. Sait who stated that the lack of awareness was the main reason for didn't have a Pap smear test [12].

The study results show that there were statistical significant differences between the practices and duration of marriage, while there were no statistical significant relationships between women's practices and (age, educational level, occupation status, and monthly income).

Shrestha and colleagues who stated that there were statistical significant relationships between Pap smear test and duration of marriage, for those who had been married for more than (20) years [10]. These results are inconsistent with Al Sairafi \& Mohamed who showed that there were statistical significant relationships between Pap smear test and socio demographic variable, which include adequate practice towards the test was significantly associated with age of the women $(\mathrm{p}=0.022)$ between $(30-49)$ years, age at first marriage ( $p=0.031$ ) , also the duration of the last doctor visit $(p=0.016)$. Bansal, et.al. (2015) found that age, income, and marital status were independent predictors of Pap smear test practice [9]. Uysal and Birsel who reported that the percent of receiving cervical screening is high among age groups between (26- 33), married women, secondary school education, urban area, medium and high income status, positive family history of the disease, and those previously informed of cervical cancer [16].

\section{Conclusion}

This study revealed that women's practices concerning cervical cancer was poor. There are statistical significant differences between cervical screening practices and duration of marriage, while there are no statistical significant differences between women's practices with the left over study variable

\section{Recommendation}

It is important to design a booklet or pamphlet about cervical cancer risk factors, signs and symptoms, screening, and prevention to reach for all women over the country in order to decrease the morbidity and mortality rate of cervical cancer.

Encouraging the married women to take responsibility for their own health and be active participants in the cervical cancer screening program regularly, and eliminate barriers to cervical cancer screening to detect the precancerous cervical lesion and provide early treatment that will prevent the disease.

\section{References}

[1] Globocan (2012), International Agency for Research on Cancer: Estimated cancer incidence, mortality and prevalence worldwide in 2012. Lyon, France: IARC; 2013. Available from: http://www. globocan.iarc.fr/.

[2] Saxena,R.: Bedside Obstetrics And Gynecology, 1st edition, Jaypee Brothers Medical Publishers, India, 2010, 400-420.

[3] Ricci,S.; Kyle,T.; Carman,S.: Maternity and pediatric nursing, $2^{\text {nd }}$ edition, Lippincott Williams \& Wilkins, Philadelphia,2013, 263-271.

[4] Ricci,S.S.: Essentials Of Maternity, Newborn, \& Women's Health Nursing, $3^{\text {rd }}$ edition, Lippincott Williams \& Wilkins, Philadelphia, 2013, 237-245.

[5] Norwitz,E.; Schorge,J.: Obstetrics and Gynecology at a Glance,4th edition, wiley-blackwell,UK,2013,67-69.

[6] Jia,Y.; Li,S.; Yang,R.; Zhou,H.; Xiang,Q.,et.al.:Knowledge about Cervical Cancer and Barriers of Screening Program among Women in Wufeng County, a High-Incidence Region of Cervical Cancer in China, Plos One,8 (7), 2013, 1-7.

[7] Callahan,T.; Caughey,A.B.: BLUEPRINTS OBSTETRICS \& GYNECOLOGY,6th edition, Lippincott Williams \& Wilkins, Philadelphia,2013,375378

[8] Lowdermilk,D.; Perry,S.; Cashion,K.; Alden,K.: Maternity \& Women's Health Care, $1^{\text {st }}$ edition,

\section{Volume 6 Issue 12, December 2017}




\section{International Journal of Science and Research (IJSR) \\ ISSN (Online): 2319-7064}

Index Copernicus Value (2016): 79.57 | Impact Factor (2015): 6.391

Mosby Elsevier, United States of America, 2012, 251260.

[9] Bansal, A.; Pakhare,A.; Kapoor,N.; Mehrotra, R.; Kokane,A.: Knowledge, attitude, and practices related to cervical cancer among adult women: A hospitalbased cross-sectional study, Journal of Natural Science, Biology and Medicine, 6 (2), 2015, 324-327.

[10] Shrestha, S.; Saha,R.; Tripathi, N.: Knowledge, Attitude and Practice regarding Cervical Cancer Screening Amongst Women visiting Tertiary Centre in Kathmandu, Nepal, NJMS, 2 (2), 2013, 85-89.

[11] Amarin, Z.; Badria,L.; Obeidat, B.: Attitudes and beliefs about cervical smear testing in ever-married Jordanian women, Eastern Mediterranean Health Journal, 14 (2), 2008, 389-395.

[12] Sait,K.H.: Attitudes, knowledge, and practices in relation to cervical cancer and its screening among women in Saudi Arabia, Saudi Med J, 30 (9), 2009, 1208-1211.

[13] John,J.: The Knowledge, Attitude, Practice And Perceived Barriers Towards Screening For Premalignant Cervical Lesions Among Women Aged 18years And Above, In Songea Urban, Ruvuma, Published dissertation, Muhimbili University of Health and Allied Sciences, (2011).

[14] AL-Sairafi, M.; Mohamed, F.: Knowledge, Attitudes, and Practice Related to Cervical Cancer Screening among Kuwaiti Women, Med Princ, 18, 2009, 35-42.

[15] Cerigo,H.; Macdonald,M.; Franco1,E.; Brassard,P.: Inuit women's attitudes and experiences towards cervical cancer and prevention strategies in Nunavik, Quebec, Int J Circumpolar Health, 71, 2012, 1-8.

[16] Uysal ,A.; Birsel, A.: Knowledge about Cervical Cancer Risk Factors and Pap Testing Behaviour among Turkish Women, Asian Pacific J Cancer Prev,10, 2009, 345350 .

Volume 6 Issue 12, December 2017

www.ijsr.net

Licensed Under Creative Commons Attribution CC BY 